\title{
LEACHING BEHAVIOR OF OIL SHALE SEMICOKE: SULPHUR SPECIES
}

\author{
H. HARZIA ${ }^{(a)}$, K. ORUPÕLD ${ }^{(b) *}$, J. HABICHT ${ }^{(a)}$, T. TENNO ${ }^{(a)}$ \\ (a) Institute of Physical Chemistry, University of Tartu \\ Jakobi 2, 51014 Tartu, Estonia \\ (b) Institute of Veterinary Medicine and Animal Sciences \\ Estonian University of Life Sciences \\ Veski 13, 51014 Tartu, Estonia
}

\begin{abstract}
Sulphide, sulphite, thiosulphate, sulphate and total sulphur were analyzed in batch leaching tests and in a percolation test to study sulphur leaching from oil shale semicoke. The results showed that thiosulphate is the major sulphur species in the semicoke leachate in the conditions of usual disposal practice.
\end{abstract}

\section{Introduction}

Production of oil from lumpy oil shale in vertical retort process results in large amounts of solid waste - semicoke. For every tonne of oil shale 0.58 tonnes of predominantly mineral (85-90\%) semicoke are formed in vertical retorts [1]. Taking into account water, the actual amount of semicoke disposed is up to 1 tonne per 1 tonne of retorted oil shale. The composition and properties of semicoke depend on the composition of oil shale and on the conditions of retorting process. High temperature during retorting results in considerable changes in the mineral part of oil shale and increases the content of potentially leachable components in the residue. However, the investigations published so far have not paid enough attention to a high content of soluble inorganic compounds in oil shale semicoke. Further more, predicting of leaching behavior and chemistry of different compounds in semicoke is very important in order to assess the environmental hazardousness of semicoke as well as to determine the applicability of different technologies for this solid waste disposal and possible reuse.

Semicoke contains a considerable amount of sulphur (1.7-2.1\%) in different forms [2], since in the retorting process of Estonian oil shale more than $50 \%$ of sulphur of the raw oil shale remains in the solid residue [3].

\footnotetext{
*Corresponding author: e-mail kaja.orupold@emu.ee
} 
Sulphur-containing compounds in oil shale undergo significant transformations during the retorting process. According to the published data, sulphur in the fresh solid residue occurs mainly in the form of calcium and iron sulphides and minor in pyrite and in sulphates [3,4]. The reaction kinetics of calcium and iron sulphide oxidation has been studied in solid as well as in aqueous systems [3]. The chemical oxidation of sulphides is quite complex because of the various products and intermediates, which can form during the course of the reaction. The major intermediates or products are elemental sulphur $\left(\mathrm{S}^{0}\right)$, thiosulphate $\left(\mathrm{S}_{2} \mathrm{O}_{3}{ }^{2-}\right)$, sulphite $\left(\mathrm{SO}_{3}{ }^{2-}\right)$ and sulphate $\left(\mathrm{SO}_{4}{ }^{2-}\right)$. It has been shown that in water the chemical oxidation of thiosulphate and sulphite can proceed at a lower rate than that of sulphide [5]. Since the further oxidation of thiosulphate is relatively slow, it can be considered a stable product in oxidation of sulphides, especially in an alkaline environment.

Data can be found about high concentration of sulphide and sulphate ions in the eluates or leachates of semicoke [2]. From the ecotoxicological tests with leachates from semicoke heaps A. Kahru with coworkers [6] concluded that the ecological risk of semicoke is up to $25 \%$ caused by soluble sulphurcontaining compounds, mostly by sulphides. However, up to now there is no systematic study carried out to evaluate the actual leaching of different sulphur species from the oil shale semicoke in Estonia.

In the present work we investigated the leachability of sulphur and its different species in the oil shale semicoke in laboratory tests with the aim to understand the behaviour of sulphur in oil shale semicoke during handling and disposal.

\section{Materials and methods}

Oil shale semicoke samples analysed in the present study were obtained from the shale oil producing company Kiviõli Keemiatööstus, Estonia. The samples were collected from the retort hydrolock outlet as subsamples of $1 \mathrm{~kg}$ and mixed together into one composite sample (12-13 kg). Large limestone fragments (particle diameter more than $5 \mathrm{~cm}$ ) were not incorporated into the composite sample.

Total sulphur and different forms of sulphur (sulphide sulphur, sulphate sulphur, pyritic sulphur and organic sulphur) in solid semicoke were determined according to the Estonian standard EVS 664:1995 for solid fuels [7].

The leaching of semicoke samples was performed according to the Estonian standard EVS-EN 12457. The tests performed were compliance tests for leaching of granular waste materials and sludges [8,9]. Compliance tests carried out were one-stage batch tests with distilled water at a liquid to solid ratio of 10 and $21 / \mathrm{kg}$. Test portions of $110 \mathrm{~g}$ and $600 \mathrm{~g}$ (as dry weight) of semicoke were used for eluate preparation in batch tests.

The leaching behavior of semicoke was also studied in a laboratory column percolation test. The percolation test was carried out with $2.2 \mathrm{~kg}$ 
(dry weight) of semicoke using $30 \mathrm{~cm}$ high columns, $10 \mathrm{~cm}$ in diameter. One column was filled with semicoke compressing it mechanically $\left(10-15 \mathrm{~kg}\right.$ per $\left.\mathrm{cm}^{2}\right)$, the other column was hand-filled and no additional pressure was applied for compaction. Water was added to the top of the column, the eluates collected from the bottom daily and analysed.

The eluates were analysed by using standard methods approved for water analysis. The total sulphur content was determined by oxidizing different sulphur compounds to sulphate with hydrogen peroxide. The sulphate sulphur formed was then determined as barium sulphate gravimetrically. Different sulphur forms in eluates $\left(\mathrm{S}^{2-}, \mathrm{S}_{2} \mathrm{O}_{3}{ }^{2-}, \mathrm{SO}_{3}{ }^{2-}\right)$ were analysed by iodometric method [10], where after precipitation of sulphides as zinc sulphide thiosulphate and sulphite were analysed in the filtrate. Sulphate concentrations were analysed by turbidimetric method. Barium chloride solution was added to the samples and the turbidity of the mixture was then measured spectrophotometrically [11]. Dr. Lange cuvette tests (LCK 353) were also used for sulphate analysis in a few samples.

\section{Results and discussion}

Seven fresh semicoke samples from Kiviõli were analysed for total sulphur content. The results obtained were between 2.1 and $3.8 \%$, with an average of $2.8 \%$. Share of different sulphur species in the studied semicoke samples is given in Table 1. The total sulphur content higher than cited in the literature [2] can be due to only partly enriched oil shale used for shale oil production in Kiviõli. In these conditions more pyrite enters the retorting process.

Results of the analysis of eluates from leaching tests are given in Table 2 and Table 3. Semicoke samples 26-32 (Table 2) were taken at different times from different retorts. Tables 2 and 3 contain data about eluates obtained according to the method recommended by the EU as standard leaching test for granular waste.

Table 1. Total sulphur content (as percentage of dry matter) in the semicoke samples and the distribution of sulphur between different forms (as percentage of total sulphur)

\begin{tabular}{|l|c|}
\hline \multicolumn{1}{|c|}{ Parameter } & Range, $\%$ \\
\hline Total sulphur & $2.1-3.8$ \\
Sulphate sulphur & $30-52$ \\
Sulphide sulphur & $9-31$ \\
Pyritic sulphur & $26-44$ \\
Organic sulphur* & $0-33$ \\
\hline
\end{tabular}

* organic sulphur was determined as the difference between the total sulphur content and the sum of sulphate, sulphide and pyritic sulphur. 
Table 2. Leaching of sulphur species from semicoke samples in batch leaching test $(\mathrm{L} / \mathrm{S} 10$ l/kg)

\begin{tabular}{|l|r|r|r|r|r|r|}
\hline \multirow{2}{*}{$\begin{array}{c}\text { Components, } \\
\mathrm{mg} / \mathrm{l}\end{array}$} & \multicolumn{7}{|c|}{ Semi-coke samples, No. } \\
\cline { 2 - 7 } & 26 & 28 & 29 & 30 & 31 & \multicolumn{1}{c|}{32} \\
\hline $\mathrm{S}^{2-}$ & 130 & 39 & 28 & 26 & 21 & 56 \\
$\mathrm{~S}_{2} \mathrm{O}_{3}{ }^{2-}$ & 351 & 258 & 524 & 434 & 248 & 248 \\
$\mathrm{SO}_{3}{ }^{2-}$ & 39 & 77 & 62 & 58 & udl & udl \\
$\mathrm{SO}_{4}{ }^{2-}$ & 80 & 130 & 144 & 231 & 117 & 65 \\
$\mathrm{~S}_{\text {total }}$ & nd & 238 & 424 & 347 & 243 & 226 \\
$\mathrm{~S}_{\text {calcul }}$ & 373 & 259 & 400 & 374 & 202 & 220 \\
\hline
\end{tabular}

udl - under detection limit; nd - not determined

Table 3. Amounts of sulphur leached from semicoke samples in batch leaching tests

\begin{tabular}{|l|c|c|c|c|}
\hline \multirow{2}{*}{$\begin{array}{l}\text { Components, } \\
\mathrm{mg} / \mathrm{kg}\end{array}$} & \multicolumn{2}{|c|}{ Amount of components leached } & \multicolumn{2}{c|}{ Amount of sulphur leached } \\
\cline { 2 - 5 } & $\mathrm{L} / \mathrm{S} 101 / \mathrm{kg}^{\mathrm{a}}$ & $\mathrm{L} / \mathrm{S} 21 / \mathrm{kg}^{\mathrm{b}}$ & $\mathrm{L} / \mathrm{S} 101 / \mathrm{kg}^{\mathrm{a}}$ & $\mathrm{L} / \mathrm{S} \mathrm{2} \mathrm{1/kg}$ \\
\hline $\mathrm{S}^{2-}$ & $210-1300$ & $180-500$ & & \\
$\mathrm{~S}_{2} \mathrm{O}_{3}{ }^{2-}$ & $2480-15900$ & $1320-19400$ & $1420-9090$ & $750-11090$ \\
$\mathrm{SO}_{3}{ }^{2-}$ & $0-770$ & $90-510$ & $0-310$ & $46-200$ \\
$\mathrm{SO}_{4}{ }^{2-}$ & $650-2310$ & $150-840$ & $220-770$ & $50-280$ \\
$\mathrm{~S}_{\text {total }}$ & $2380-11000$ & $1476-11600$ & & \\
\hline
\end{tabular}

$\mathrm{a}-8$ samples; $\mathrm{b}-5$ samples

The results about total sulphur in the eluates indicate that $1.5-11.6 \mathrm{~g}$ sulphur per kg of dry matter of semicoke leached in the batch tests. This strongly depends on the semicoke sample, but as can be seen from Table 3 the quantities of different sulphur species leaching from semicoke vary significantly when different leachate/semicoke (L/S) ratios are applied in the batch tests. The results indicate that when preparing the leaching test according to the standard method, sulphur leaches to great extent as thiosulphate, which is a stable intermediate of sulphide sulphur oxidation. In the analysed samples thiosulphate sulphur formed $58-96 \%$ of the total sulphur in the eluates. In the method applied for analysis of different sulphur species the sulphite concentrations were determined as the difference of two measurements. For this reason uncertainty of the measurements in sulphite analysis is the highest. The calculated sum of sulphur in different species $\left(S_{\text {calcul }}\right)$ is also given in Table 2 for every sample. There is a good agreement with the results of calculated sums and the total sulphur measurements.

It is known from earlier studies [3] that oxidation of iron sulphide can occur in semicoke and that calcium sulphide hydrolyzes easily, and hydrogen sulphide ion in water in turn oxidizes to thiosulphate and sulphate. Therefore, it is likely that the results of the leaching of sulphur-containing compounds depend very much on the conditions of sampling, sample 
storage, sample handling etc. The leaching of sulphur species from one sample after different time intervals was also investigated. The studied semicoke was stored in a closed container, but no more special measures were undertaken to avoid contact with air. Table 4 illustrates changes in the leachate composition. The increase in the total amount of leachable sulphur as well as the change in proportions of different compounds indicate the changes taking place in the semicoke samples during storage.

The results from the percolation test are presented in figure. It can be seen how the leaching of sulphur from mechanically compacted (column 2) and non-compacted (column 1) semicoke changes with time.

The percolation test also shows that thiosulphate is the major sulphur species in the oil shale semicoke leachate and a stable ion in alkaline conditions.

Table 4. Leaching of different sulphur species from fresh semicoke and after different storage periods $(\mathrm{L} / \mathrm{S} 2 \mathrm{l} / \mathrm{kg})$

\begin{tabular}{|l|c|c|cc|}
\hline Components, $\mathrm{mg} / \mathrm{l}$ & Fresh semicoke & 3 days old semicoke & \multicolumn{2}{|c|}{ 40 days old semicoke } \\
\hline $\mathrm{S}^{2-}$ & 273 & 176 & 96 & $82^{*}$ \\
$\mathrm{~S}_{2} \mathrm{O}_{3}{ }^{2-}$ & 660 & 1457 & 5717 & $5826^{*}$ \\
$\mathrm{SO}_{3}{ }^{2-}$ & 254 & 280 & 0 & $118^{*}$ \\
$\mathrm{SO}_{4}{ }^{2-}$ & 347 & nd & nd & \\
\hline
\end{tabular}

$*$ - leachate was stored for 2 days at room temperature

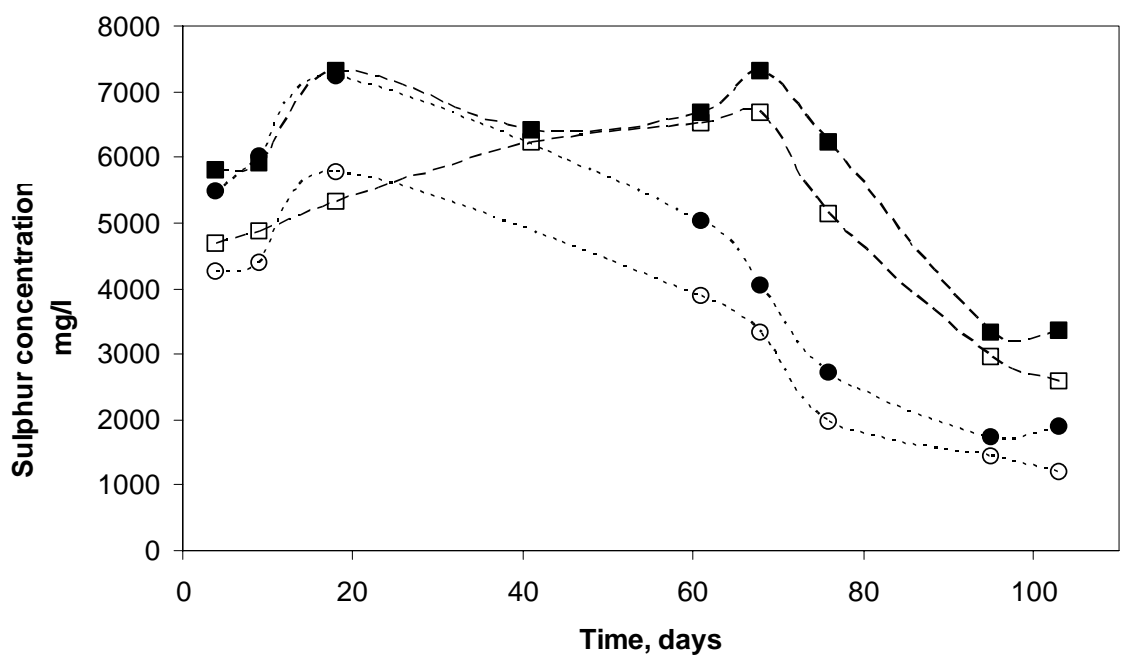

Figure. Sulphur concentrations (mg/l) in the leachates from the percolation test.

- - column 1 , total sulphur; $\square$ - column 1 , thiosulphate sulphur; $\bullet$ - column 2 , total sulphur, $\circ-$ column 2 , thiosulphate sulphur. 
One aspect of this study is strongly connected with chemical analysis of different sulphur species. It has been recognized that several methods of chemical analysis which are appropriate for relatively simple wastewaters are not appropriate for wastewaters from retort processes or wastes [12]. This situation can be explained with the presence of large number of interfering components in these waters for which the standard methods are not designed. For example, the iodometric titration and the methylene blue colorimetric method [11], which are most commonly used for measuring sulphide in wastewater samples, suffer interference from reducing agents. Therefore, applying these methods for analysis of semicoke leachates or eluates can not give reliable results if the other oxidizable sulphur species, such as thiosulphate or sulphite, are present. High concentrations of sulfates in the leachates originating from the embankments have often been measured with the turbidimetric method [11]. When analysing the leachates in this study we saw that precipitates formed during analysis even without adding a special analyte - barium chloride. We suggest that the presence of high concentrations of thiosulphate gives a strong interference also in the case of sulphate determination. Taking into account the above mentioned shortages of the methods most often used for analysis of different sulphur species in waters, critical evaluation of the results must be carried out if the same methods have been used to analyze the leachates or eluates of oil shale semicoke.

\section{Conclusions}

In the retorting process of Estonian lumpy oil shale in internally heated vertical retorts more than a half of the sulphur present in the raw material is left in the solid residue - semicoke. Although most of the leachable sulphur in semicoke is in the form of sulphides, the form most dangerous to the environment, the waste is exposed to water and air straight after leaving the retort and during disposal, the conditions favoring sulphide oxidation. Studying the leaching of different sulphur compounds from semicoke has shown that thiosulphate is the major sulphur-containing ion in the semicoke leachate. Thiosulphate is an important intermediate in sulphur exchange between sulphide and sulphate in the semicoke leachates. It is probably a result of incomplete oxidation of sulphide, which occurs rapidly even during brief exposures to oxygen and transforms further relatively slowly over a longer period of time.

\section{Acknowledgement}

Financial support by the Estonian Science Foundation (Grant No. 5811) is gratefully acknowledged. 


\section{REFERENCES}

1. Veski, $R$. The volumes of spent oil shale from Estonian oil-shale processing units in 1921-2002 // Oil Shale. 2005. Vol. 22, No. 3. P. 345-357.

2. Environmental hazard assessment of semi-coke // Estonian Environmental Research Centre Report. Tallinn, 2003 [in Estonian]. (http://www.envir.ee/ jaatmed/poolkoksi_uuring.pdf).

3. Mölder, L., Elenurm, A., Tamvelius, H. Sulphur compounds in a hydraulic ashdisposal system // Proc. Estonian Acad. Sci. Chem. 1995. Vol.44, No. 2/3. P. 207-211.

4. Yefimov, V., Doilov, S., Lööper, R., Soo, M. On the possibility of preventing the formation of water-soluble sulfide sulfur at processing of oil shale in gas generators // Oil Shale. 1984. Vol. 1, No. 2. P. 179-188.

5. Nielsen, A. H., Vollersten, J., Hvitve-Jacobsen, T. Determination of kinetics and Stoichiometry of chemical sulfide oxidation in wastewater of sewer networks // Environ. Sci. Technol. 2003. Vol. 37, No. 17. P. 3853-3858.

6. Kahru, A., Kurvet, M., Kurvet, I. Study of the toxicological impact of different components of ash-heap water (sulphur rich phenolic leachate) using luminescent bacteria as test organisms // Oil Shale. 1997. Vol. 14, No. 4 Special. P. 469-475.

7. EVS 644:1995. Solid fuels sulphur content. Determination of total sulphur and its bonding forms. Eesti Standardiamet, 1995.

8. EVS-EN 12457-1:2002, Characterisation of waste - Leaching - Compliance test for leaching of granular waste materials and sludges - Part 1: One stage batch test at a liquid to solid ratio of $21 / \mathrm{kg}$ for materials with particle size below $4 \mathrm{~mm}$ (without or with size reduction). Eesti Standardikeskus, 2002.

9. EVS-EN 12457-4:2002, Characterisation of waste - Leaching - Compliance test for leaching of granular waste materials and sludges - Part 4: One stage batch test at a liquid to solid ratio of $101 / \mathrm{kg}$ for materials with particle size below 10mm (without or with size reduction). Eesti Standardikeskus, 2002.

10. Lure, J., J., Rybnikova, A. M. Chemical analysis of wastewater. - Moscow, 1974 [in Russian].

11. American Public Health Association. Standard Methods for the Examination of Water and Wastewater. - Washington D.C., 1986.

12. Wallace, J. R., Alden, L., Bonomo, F., Sexton, E. Analytical methods for oil shale wastes // Oil Shale Symp. Proc., 15th. 1982. P. 573-580.

Presented by L. Mölder

Received May 9, 2007 